\title{
Outcomes in Living Donor Kidney Transplantation: The Role of Donor's Kidney Function
}

\author{
Massimo Torreggiani ${ }^{a}$ Ciro Esposito $^{b, c}$ Elena Martinellic ${ }^{c}$ Thomas Jouve ${ }^{d, e}$ \\ Antoine Chatrenet $^{a}$ Lionel Rostaing ${ }^{d, e}$ Marco Colucci ${ }^{b}$ Ettore Pasquinuccib, $c$ \\ Giuseppe Sileno $^{b}$ Vittoria Esposito ${ }^{b}$ Giorgina B. Piccolia, ${ }^{f}$ Paolo Malvezzi ${ }^{d}$ \\ ${ }^{a}$ Nephrology and Dialysis, Centre Hospitalier Le Mans, Le Mans, France; ${ }^{b}$ Unit of Nephrology and Dialysis, ICS \\ Maugeri S.p.A., Pavia, Italy; 'CDipartimento di Medicina Interna e Terapia Medica, Università di Pavia, Pavia, Italy; \\ 'Service de Néphrologie, Hémodialyse, Aphérèses et Transplantation, Centre Hospitalier Universitaire Grenoble \\ Alpes, Grenoble, France; 'Université Grenoble Alpes, Grenoble, France; fDipartimento di Scienze Cliniche e \\ Biologiche, Università di Torino, Torino, Italy
}

\section{Keywords}

Chronic patients · Kidney transplant · Living donor · Survival · Chronic kidney disease

\begin{abstract}
Introduction: Living donor kidney transplant (LDKT) is one of the best therapeutic options for end-stage kidney disease (ESKD). Guidelines identify different estimated glomerular filtration rate (eGFR) thresholds to determine the eligibility of donors. The aim of our study was to evaluate whether pretransplant donor eGFR was associated with kidney function in the recipient. Methods: We retrospectively studied LDKT recipients who received a kidney graft between September 1,2005 , and June 30, 2016 in the same transplant center in France and that had eGFR data available at 3, 12, 24, and 36 months posttransplant. Results: We studied 90 donor-recipient pairs. The average age at time of transplant was $51.47 \pm$ 10.95 for donors and $43.04 \pm 13.52$ years for recipients. Donors' average eGFR was $91.99 \pm 15.37 \mathrm{~mL} / \mathrm{min} / 1.73 \mathrm{~m}^{2}$. Donor's age and eGFR were significantly correlated $(p<0.0001$, $r^{2}$ 0.023). Donor's age and eGFR significantly correlated with recipient's eGFR at 3, 12, and 24 months posttransplant (age: $p<0.001$ at all intervals; eGFR $p=0.001,0.003$, and 0.016,
\end{abstract}

respectively); at 36 months, only donor's age significantly correlated with recipient's eGFR. BMI, gender match, and year of kidney transplant did not correlate with graft function. In the multivariable analyses, donor's eGFR and donor's age were found to be associated with graft function; correlation with eGFR was lost at 36 months; and donor's age retained a strong correlation with graft function at all intervals $(p<0.001)$. Conclusions: Donor's eGFR and age are strong predictors of recipient's kidney function at 3 years. We suggest that donor's eGFR should be clinically balanced with other determinants of kidney function and in particular with age.

(c) 2021 The Author(s)

Published by S. Karger AG, Basel

\section{Introduction}

Since the first successful kidney transplant, living donor kidney transplant (LDKT) has been considered the best therapeutic option for end-stage kidney disease (ESKD) [1-5]. One of the most important premises of a

Massimo Torreggiani and Ciro Esposito, and Giorgina Barbara Piccoli and Paolo Malvezzi contributed equally to this work.
(C) 2021 The Author(s)

Published by S. Karger AG, Basel

This is an Open Access article licensed under the Creative Commons Attribution-NonCommercial-4.0 International License (CC BY-NC) (http://www.karger.com/Services/OpenAccessLicense), applicable to the online version of the article only. Usage and distribution for commercial purposes requires written permission.
Massimo Torreggiani

Nephrology and Dialysis, Centre Hospitalier Le Mans

194 Avenue Roubillard

FR-72000 Le Mans (France)

maxtorreggiani@hotmail.com 
Table 1. Donor eligibility according to different guidelines

\begin{tabular}{|c|c|c|c|c|c|c|}
\hline Guideline & Year & Acceptable eGFR, $\mathrm{mL} / \mathrm{min} / 1.73 \mathrm{~m}^{2}$ & $\begin{array}{l}\text { Age } \\
\text { limit }\end{array}$ & BMI limit & $\begin{array}{l}\text { Gender } \\
\text { match }\end{array}$ & $\begin{array}{l}\text { Kidney } \\
\text { size }\end{array}$ \\
\hline British transplantation society [16] & 2018 & $\geq 49$ according to age and gender & No & No $\left(\right.$ caution if $>30 \mathrm{~kg} / \mathrm{m}^{2}$ ) & na & na \\
\hline KDIGO [15] & 2017 & $\geq 90$ (caution between 60 and 89 ) & No & No (caution if $>30 \mathrm{~kg} / \mathrm{m}^{2}$ ) & na & na \\
\hline ERBP [14] & 2015 & $\geq 80$ if older than 50 & No & $>35 \mathrm{~kg} / \mathrm{m}^{2}$ (caution if $\left.\geq 30 \mathrm{~kg} / \mathrm{m}^{2}\right)$ & na & na \\
\hline
\end{tabular}

eGFR, estimated glomerular filtration rate.

successful transplant is careful selection of the donor: age, kidney function, gender match, and body weight have all been associated with increased rates of graft survival [68].

Overall, kidney donation is safe [9-11] although a few studies suggest a small but significant increase in the risk of ESKD among kidney donors $[12,13]$. While the risk remains very low, it has been associated with the occurrence of de novo kidney diseases [12] or secondary to obesity, diabetes, and hypertension, all of which have increased in the general population in the last 2 decades [13].

The glomerular filtration rate (GFR) threshold for allowing kidney donation is not univocally defined and ranges in the current guidelines go from 50 to $90 \mathrm{~mL} /$ $\mathrm{min} / 1.73 \mathrm{~m}^{2}$ (Table 1) [14-16]. KDIGO guidelines indicate a GFR of $90 \mathrm{~mL} / \mathrm{min}$ per $1.73 \mathrm{~m}^{2}$ or greater as acceptable for donation and suggest, in case of GFR between 60 and $89 \mathrm{~mL} / \mathrm{min}$ per $1.73 \mathrm{~m}^{2}$, that the decision be based on demographic and health profile; a GFR lower than $60 \mathrm{~mL} /$ min per $1.73 \mathrm{~m}^{2}$ is considered a contraindication for donation [15]. However, after the release of the guidelines, some authors advised for caution when evaluating donors with an estimated GFR (eGFR) between 60 and $89 \mathrm{~mL} /$ min per $1.73 \mathrm{~m}^{2}$ [17]. According to the British Transplantation Society guidelines for living kidney donor transplantation, the safe threshold of pre-donation kidney function is one that leaves sufficient function after donation to maintain the donor in normal health (or minimal absolute reduction of health) without affecting lifespan [16]; this threshold is modulated according to age and gender.

The shortage of organs and the decrease in LDKT in some countries are valid reasons to try to expand selection criteria for donors. In 2006, the term "complex living donors" was introduced to define donors that did not fit into the profile suggested by guidelines but that could still be eligible for donation in the absence of clear contraindications [18]. Occasional reports indicate that kidney donation may be performed without complications with complex living donors, even with eGFR below $45 \mathrm{~mL} / \mathrm{min}$ $[19,20]$. However, most transplant centers consider 80 $\mathrm{mL} / \mathrm{min} / 1.73 \mathrm{~m}^{2}$ as the threshold for donor eligibility, and this choice increased from 67 to $74 \%$ between 2005 and 2017 in the USA, while the prevalence of centers accepting as their lower limit 2 standard deviations below the expected-for-age eGFR decreased from 25 to $22 \%$ [21]. It has been suggested that donor's kidney function should be evaluated considering age and expected survival of both donor and recipient, as older donors with mildly reduced kidney function could be a resource to answer the growing demand for kidney transplant in elderly patients $[22,23]$.

Almost intuitively, a donor with low GFR has been associated with a higher risk of graft loss [24] or reduced graft function at 1 year [25], but a large study in the USA found no differences dichotomizing donor's eGFR at 80 $\mathrm{mL} / \mathrm{min}$ [26]. In fact, the long-term effect of donor's kidney function, in the current accepted ranges on the recipient's kidney function, is still debated and few studies assessed this issue (Table 2). In this context, we aimed to review the characteristics of living kidney donors at a single referral kidney transplant center with significant LKDT activity, in order to test the effect of donor's eGFR and to identify other variables that could contribute to modulating selection criteria.

\section{Methods}

\section{Study Population}

We retrospectively evaluated all consecutive adult living kidney transplant donor-recipient pairs that had undergone transplantation between September 1, 2005, and July 30, 2016, at the Centre Hospitalier Universitaire in Grenoble, the third largest LDKT center in France. The immunosuppression protocol at the center consists in thymoglobulin-based induction therapy and maintenance therapy with calcineurin inhibitors (mainly tacrolimus) plus mycophenolate mofetil, in the context of an early steroid withdrawal policy, within 3 months from transplantation. Follow-up data up to 3 
Table 2. Studies assessing the effect of donor's kidney function on recipient's graft function [24-26, 52-54]

\begin{tabular}{|c|c|c|c|c|c|}
\hline Study & $\begin{array}{l}\text { Donor- } \\
\text { recipient } \\
\text { pairs }\end{array}$ & $\begin{array}{l}\text { Donor's } \\
\text { GFR }\end{array}$ & Method & $\begin{array}{l}\text { Correlation } \\
\text { between donor's } \\
\text { and recipient's } \\
\text { kidney function }\end{array}$ & Notes \\
\hline Norden et al. [24] & 344 & Measured & ${ }^{51}$ Crom-EDTA & Yes & $\begin{array}{l}\text { Donor's } \mathrm{mGFR}<80 \mathrm{~mL} / \mathrm{min} / 1.73 \mathrm{~m}^{2} \text { increase the risk } \\
\text { of graft loss }\end{array}$ \\
\hline Poggio [52] & 119 & Measured & $\begin{array}{l}{ }^{125} \text { I-iothalamate urinary } \\
\text { clearance }\end{array}$ & Yes & $\begin{array}{l}\text { Transplanted kidney GFR }>55 \mathrm{~mL} / \mathrm{min} / 1.73 \mathrm{~m}^{2} \\
\text { associated with better recipient's kidney function at } 2 \\
\text { years }\end{array}$ \\
\hline Issa [53] & 248 & Measured & $\begin{array}{l}{ }^{125} \text { I-iothalamate urinary } \\
\text { clearance }\end{array}$ & Yes & $\begin{array}{l}\text { Donor's iGFR }>110 \mathrm{~mL} / \mathrm{min} \text { was associated with a } \\
\text { better recipient's renal function at } 2 \text { years }\end{array}$ \\
\hline Chang [54] & 83 & Estimated & MDRD equation & No & \\
\hline Young et al. [26] & 2,057 & Estimated & CKD-EPI equation & No & $\begin{array}{l}\text { No differences in graft survival between donor's with } \\
\text { eGFR }>\text { or }<80 \mathrm{~mL} / \mathrm{min} / 1.73 \mathrm{~m}^{2}\end{array}$ \\
\hline
\end{tabular}

mGFR, measured glomerular filtration rate; iGFR, glomerular filtration rate measured by ${ }^{125}$ I-iothalamate urinary clearance; eGFR, estimated glomerular filtration rate.

years after kidney transplant were assessed on June 30, 2019. Pairs with incomplete data on recipient's kidney function were excluded.

\section{Outcome Measures}

For donors, we collected demographic data, serum Cr, eGFR calculated according to the CKD-EPI equation [27], bipolar kidney length, as measured by ultrasound and BMI at the time of donation. For recipients, we collected demographic data and serum $\mathrm{Cr}$ and eGFR calculated according to the CKD-EPI equation at 3, 12,24 , and 36 months posttransplant with a tolerance of \pm 1 month at each time point.

\section{Statistical Analysis}

Statistical analysis was performed using GraphPad Prism software v7.0 (GraphPad Software, La Jolla, CA, USA) and SPSS v23.0 (IBM Corp., Foster city, CA, USA). Parametric data are presented as mean \pm standard deviation, while categorical variables are given as percentages or absolute numbers. Quantitative variables were compared using the one- or two-way ANOVA followed by Tukey's multiple comparisons test, while qualitative variables were compared by means of Fisher's exact test. Linear regression was assessed between recipient's eGFR and donor's eGFR, age, BMI, and kidney size at each time point (i.e., 3, 12, 24, and 36 months). Logistic regression was assessed between recipient's eGFR (used as a continuous variable) and gender match (yes or no) and year of transplant (dichotomized at the median which was 2012) at each time point. Noncollinear, statistically, or clinically significant covariates were analyzed by multiple variable regression analysis. Correlation of the explanatory variables was tested by means of the Pearson correlation test and the multivariable regression model and verified using residual analysis (available as online suppl. material; for all online suppl. material, see www.karger.com/doi/10.1159/000512177). A $p<0.05$ was considered statistically significant.

\section{Results}

\section{Baseline Data}

From September 1, 2005, to June 30, 2016, 136 living donor kidney transplantations were performed in the study center. Kidney function data at baseline (donor and recipient) and recipient data at all intervals were available in 90 cases. The mean age at transplantation was $51.47 \pm$ 10.95 for donors and $43.04 \pm 13.52$ for recipients. Of the 58 recipients, 26 were men. Donors' mean CKD-EPI eGFR was $91.99 \pm 15.37 \mathrm{~mL} / \mathrm{min} / 1.73 \mathrm{~m}^{2}$ (Table 3; Fig. 1).

\section{Descriptive Analysis}

The 90 donor-recipient pairs were divided into tertiles according to donor's eGFR: (i) $<85.33 \mathrm{~mL} / \mathrm{min} / 1.73 \mathrm{~m}^{2}$, (ii) between 85.33 and $98.30 \mathrm{~mL} / \mathrm{min} / 1.73 \mathrm{~m}^{2}$, and (iii) $>98.30 \mathrm{~mL} / \mathrm{min} / 1.73 \mathrm{~m}^{2}$ (Table 4). All subjects were Caucasians except 1 donor-recipient couple in the third tertile that was of African descent. For 6 recipients, this was the second kidney transplant ( 1 in the first, 2 in the second, and 3 in the third tertile).

One patient in the first tertile experienced an acute cellular rejection at month 12,2 patients in the second tertile experienced a relapse of baseline disease (sarcoidosis and focal segmental glomerulosclerosis), and 1 patient in the third tertile had a relapse of baseline disease (focal segmental glomerulosclerosis). No donor or recipient died or required dialysis during the period studied. Overall, 


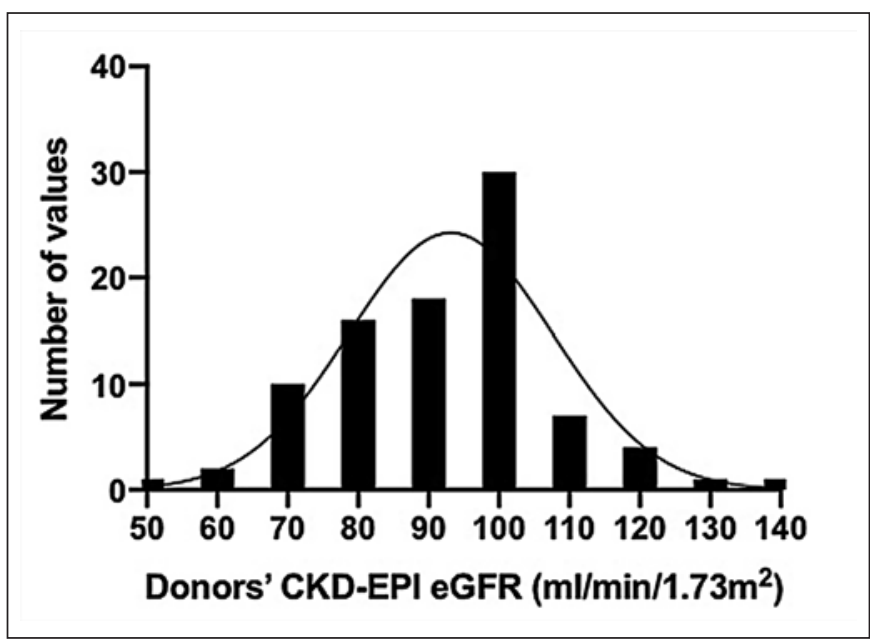

Fig. 1. Donors' eGFR distribution in our cohort. eGFR, estimated glomerular filtration rate.

Table 3. Baseline characteristics of donors and recipients

\begin{tabular}{|c|c|c|}
\hline & $\begin{array}{l}\text { Donors, } \\
n=90\end{array}$ & $\begin{array}{l}\text { Recipients, } \\
n=90\end{array}$ \\
\hline Age at transplant, years & $51.47 \pm 10.95$ & $43.04 \pm 13.52$ \\
\hline Gender (male), $n(\%)$ & $26(28.9)$ & $58(64.4)$ \\
\hline CKD-EPI eGFR, $\mathrm{mL} / \mathrm{min} / 1.73 \mathrm{~m}^{2}$ & $91.99 \pm 15.37$ & na \\
\hline Kidney size, mm & $108.89 \pm 10.33$ & na \\
\hline $\mathrm{BMI}, \mathrm{kg} / \mathrm{m}^{2}$ & $24.28 \pm 3.57$ & na \\
\hline
\end{tabular}

eGFR, estimated glomerular filtration rate.

recipients in the third tertile had better renal function during the entire follow-up compared to patients in the first tertile $(p<0.05)$ (Fig. 2).

\section{Univariate Regression Analysis}

Donor's kidney function positively correlated with graft function at 3,12 , and 24 months $(p=0.001,0.03$, and 0.016 , respectively) but not at 36 months (Table 5). Donor's age and donor's kidney function were significantly and inversely correlated $\left(p<0.0001, r^{2} 0.323\right)$.

Moreover, donor's age showed an inverse correlation with recipient's kidney function at all time points (Table 5). Figure 3 shows recipient's kidney function dichotomized according to median age of donors. Donor's kidney size showed a direct correlation with recipient's graft function, reaching statistical significance at 12 and 24 months ( $p=0.034$ and 0.014 , respectively) (Table 5). Do- nor's BMI, donor-recipient gender match, and the year of transplant were not significantly correlated with recipient's kidney function (Table 5).

\section{Multiple Variable Linear Regression Analysis}

Since donor's eGFR and donor's age displayed collinearity, we tested them separately in 2 multivariate models: model 1 - donor's eGFR, BMI, and kidney size and model 2 - donor's age, BMI, and kidney size. BMI was included in the model due to its clinical relevance [28].

No collinearity was detected between donor's BMI, eGFR, and kidney size. Donor's eGFR was significantly associated with recipient's eGFR up to month 24 of follow-up (Table 6). Donor's age was independently associated with recipient's kidney function at each time point (Table 7). Donor's BMI was significantly correlated with graft function up to 24 months in the second multiple variable regression model (Table 7).

A third model was subsequently designed to adjust for the effect of donor's age and eGFR together. In this model, donor's BMI was significantly correlated with graft function for up to 24 months (Table 8). The appropriateness of each model was verified using residual analysis (available as see online suppl. material).

\section{Discussion}

Living kidney graft, whose results depend upon a careful selection of donor and recipient, has proved to be an optimal treatment option for ESKD [29]. Different guidelines suggest different eGFR thresholds for donation, and it is still not known whether mildly reduced renal function affects graft function (Table 2). The aim of our study was to gather information that could contribute to answering this question. For this purpose, we decided to study 90 donor-recipient pairs with complete data on recipients over their 3 -year posttransplant follow-up period. As expected, higher donor eGFR was generally associated with better eGFR in the recipient.

However, this is the main finding of the study, the effect on donor's kidney function progressively decreased during time and significance was lost at 36 months posttransplant. Conversely, relationship with donor's age is significant at all time points. Since age and eGFR show a strong inverse correlation, this suggests that donor's age is a leading element in determining the effect on recipient's eGFR. Of note, however, is the fact that the slope of the eGFR curve in recipients is similar, even when the 


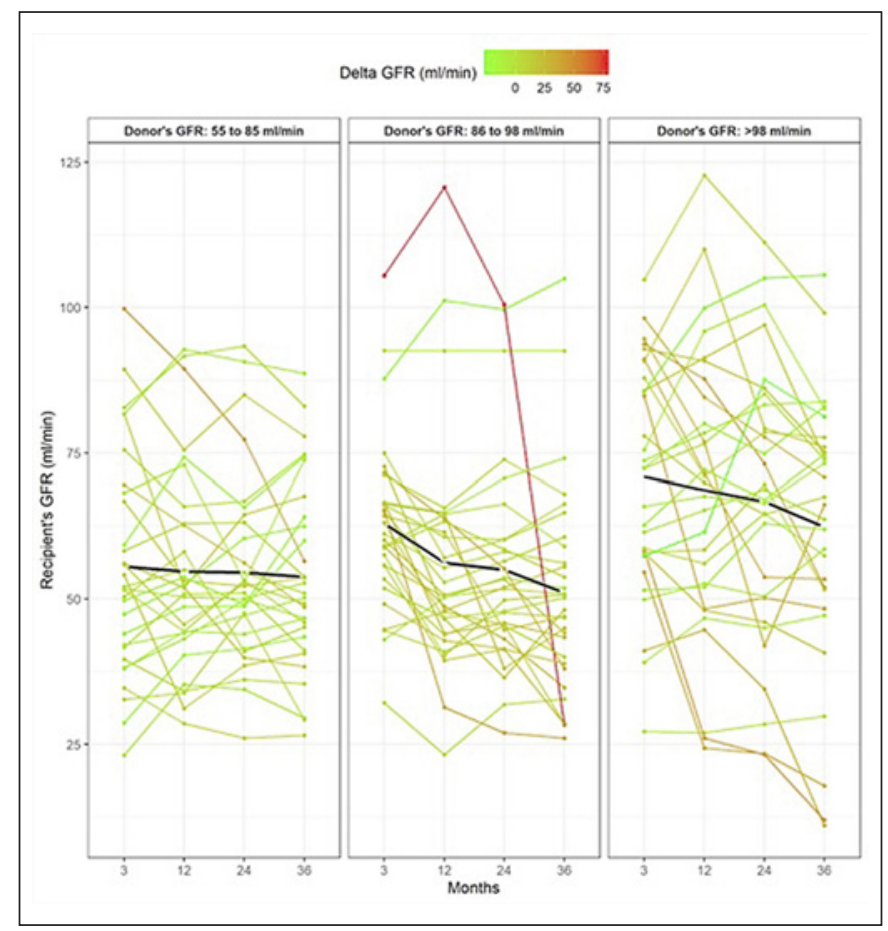

Fig. 2. Individual recipients' eGFR evolution during follow-up according to tertile of donor's kidney function. Black lines represent the recipient's average eGFR trend inside the tertile group during follow-up ( $p<0.05$ tertile III vs. I). eGFR, estimated glomerular filtration rate.

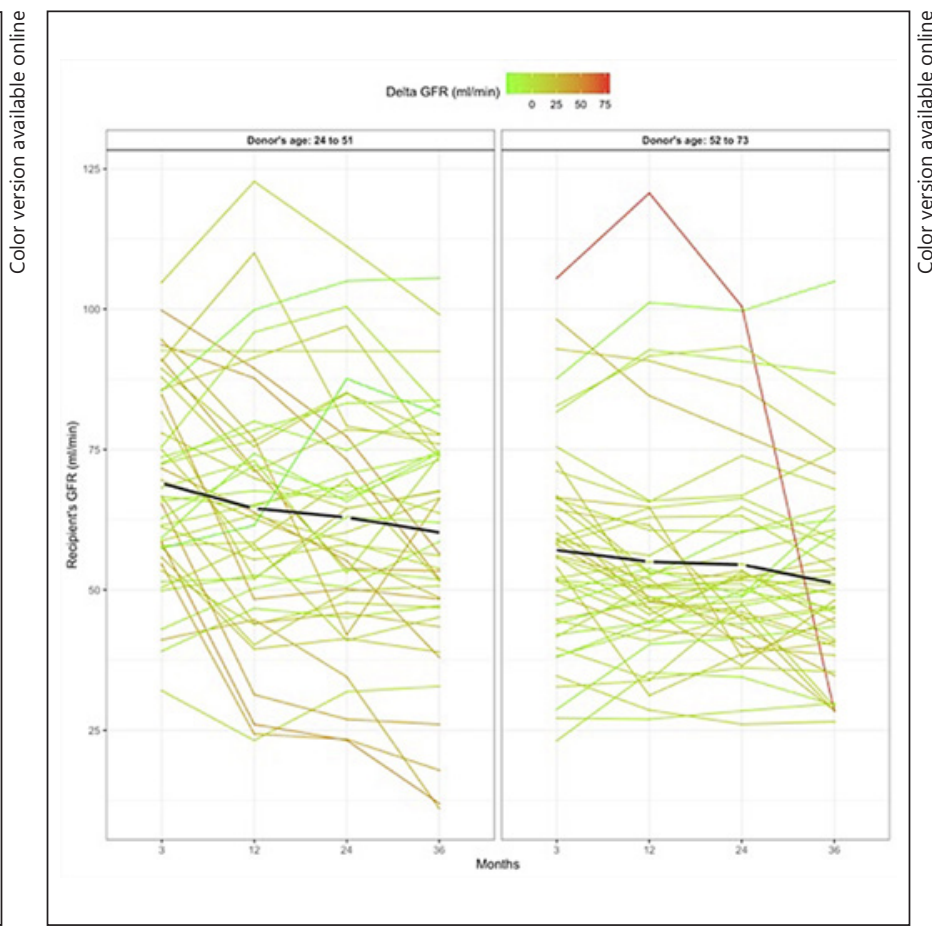

Fig. 3. Individual recipients' eGFR evolution during follow-up according to median donor's age. Black lines represent the recipients' average eGFR trend inside the group during follow-up. eGFR, estimated glomerular filtration rate.

Table 4. Recipients' baseline characteristics divided into tertiles according to donor's renal function

\begin{tabular}{|c|c|c|c|c|}
\hline & $\begin{array}{l}\text { I tertile } \\
(n=30)\end{array}$ & $\begin{array}{l}\text { II tertile } \\
(n=30)\end{array}$ & $\begin{array}{l}\text { III tertile } \\
(n=30)\end{array}$ & $p$ value \\
\hline Donor age at transplant, years & $58.10 \pm 8.04$ & $53.50 \pm 8.95$ & $42.80 \pm 9.30$ & $<0.001$ I versus III and II versus III \\
\hline Recipient age at transplant, years & $44.20 \pm 14.82$ & $44.87 \pm 12.20$ & $40.07 \pm 13.36$ & ns \\
\hline Donor gender (male) & 5 & 10 & 11 & ns \\
\hline Recipient gender (male) & 18 & 18 & 22 & ns \\
\hline Donor-recipient age difference, years & $13.90 \pm 14.98$ & $8.63 \pm 13.90$ & $2.73 \pm 10.10$ & $<0.01$ I versus III \\
\hline Donor-recipient gender match $(\mathrm{f}>\mathrm{m})$ & 16 & 16 & 16 & - \\
\hline Donor-recipient gender match $(f>f)$ & 9 & 4 & 3 & - \\
\hline Donor-recipient gender match $(\mathrm{m}>\mathrm{f})$ & 3 & 8 & 5 & - \\
\hline Donor-recipient gender match $(\mathrm{m}>\mathrm{m})$ & 2 & 2 & 6 & - \\
\hline Donor CKD-EPI eGFR, $\mathrm{mL} / \mathrm{min} / 1.73 \mathrm{~m}^{2}$ & $74.95 \pm 8.04$ & $93.44 \pm 3.73$ & $107.58 \pm 11.36$ & $<0.001$ \\
\hline Donor kidney size, $\mathrm{mm}$ & $107.50 \pm 11.45$ & $109.14 \pm 7.64$ & $110.12 \pm 11.36$ & ns \\
\hline Donor BMI & $24.38 \pm 3.58$ & $24.11 \pm 3.44$ & $24.36 \pm 3.79$ & ns \\
\hline Year of transplant $\leq 2012$ & 16 & 20 & 15 & - \\
\hline
\end{tabular}

eGFR, estimated glomerular filtration rate. 
Table 5. Univariate regression analysis between different donor characteristics and recipients' kidney function over follow-up

\begin{tabular}{|c|c|c|c|c|c|c|c|}
\hline & \multirow[t]{2}{*}{$B$} & \multicolumn{2}{|l|}{ CI 95\% } & \multirow[t]{2}{*}{ Odds ratio } & \multicolumn{2}{|c|}{ CI 95\% } & \multirow[t]{2}{*}{$p$ value } \\
\hline & & lower & higher & & lower & higher & \\
\hline \multicolumn{8}{|c|}{ Donor's eGFR } \\
\hline 3 months & 0.419 & 0.176 & 0.662 & 1.520 & 1.192 & 1.939 & 0.001 \\
\hline 12 months & 0.426 & 0.147 & 0.705 & 1.531 & 1.158 & 2.024 & 0.003 \\
\hline 24 months & 0.331 & 0.064 & 0.597 & 1.392 & 1.066 & 1.817 & 0.016 \\
\hline 36 months & 0.250 & -0.017 & 0.517 & 1.284 & 0.983 & 1.677 & 0.066 \\
\hline \multicolumn{8}{|l|}{ Donor's age } \\
\hline 3 months & -0.254 & -0.365 & -0.143 & 0.776 & 0.694 & 0.867 & $<0.001$ \\
\hline 12 months & -0.208 & -0.307 & -0.108 & 0.812 & 0.736 & 0.898 & $<0.001$ \\
\hline 24 months & -0.22 & -0.327 & -0.114 & 0.803 & 0.721 & 0.892 & $<0.001$ \\
\hline 36 months & -0.214 & -0.322 & -0.105 & 0.807 & 0.725 & 0.9 & $<0.001$ \\
\hline \multicolumn{8}{|l|}{ Kidney size } \\
\hline 3 months & 0.102 & -0.021 & 0.225 & 1.107 & 0.979 & 1.252 & 0.102 \\
\hline 12 months & 0.119 & 0.009 & 0.229 & 1.126 & 1.009 & 1.257 & 0.034 \\
\hline 24 months & 0.145 & 0.03 & 0.26 & 1.156 & 1.03 & 1.297 & 0.014 \\
\hline 36 months & 0.071 & -0.056 & 0.198 & 1.074 & 0.946 & 1.219 & 0.271 \\
\hline \multicolumn{8}{|c|}{ Donor's BMI } \\
\hline 3 months & 0.025 & -0.014 & 0.065 & 1.025 & 0.986 & 1.067 & 0.208 \\
\hline 12 months & 0.033 & -0.002 & 0.068 & 1.034 & 0.998 & 1.07 & 0.063 \\
\hline 24 months & 0.034 & -0.003 & 0.071 & 1.035 & 0.997 & 1.074 & 0.074 \\
\hline 36 months & 0.022 & -0.017 & 0.06 & 1.022 & 0.983 & 1.062 & 0.264 \\
\hline \multicolumn{8}{|c|}{ Gender match } \\
\hline 3 months & -0.015 & -0.017 & 0.004 & 0.986 & 0.962 & 1.01 & 0.247 \\
\hline 12 months & -0.019 & -0.018 & 0.001 & 0.981 & 0.96 & 1.002 & 0.082 \\
\hline 24 months & -0.01 & -0.014 & 0.005 & 0.99 & 0.968 & 1.012 & 0.373 \\
\hline 36 months & -0.018 & -0.018 & 0.003 & 0.982 & 0.959 & 1.006 & 0.136 \\
\hline \multicolumn{8}{|c|}{ Year of transplant } \\
\hline 3 months & -0.009 & -0.014 & 0.006 & 0.991 & 0.969 & 1.014 & 0.431 \\
\hline 12 months & 0.000 & -0.008 & 0.009 & 1.000 & 0.981 & 1.020 & 0.999 \\
\hline 24 months & 0.004 & -0.007 & 0.011 & 1.004 & 0.983 & 1.026 & 0.702 \\
\hline 36 months & 0.010 & -0.005 & 0.014 & 1.010 & 0.989 & 1.032 & 0.354 \\
\hline
\end{tabular}

starting point is different, when dichotomizing for donor's age at the median of 51 years (Fig. 3). Likewise, recipients of kidneys from donors in the lowest eGFR tertile do not display a steeper decrease in eGFR compared to those grafted from a donor in a higher tertile. Our data are in keeping with the observations of Young and colleagues [26] who did not find differences in graft function in recipients from donors with an eGFR lower or $>80 \mathrm{~mL} /$ $\mathrm{min} / 1.73 \mathrm{~m}^{2}$.

Aging is associated with loss of kidney function, and thus, age and glomerular filtration rate are closely related $[30,31]$. There is no general agreement on whether the definition of CKD should be changed to account for the changes observed in the elderly [32-34]. Nevertheless, elderly people have a reduced functional reserve even when GFR has been preserved [35]. Guidelines do not set an upper limit for donor age [15], but some do recommend caution when potential donors are older than 50 [14] or 60 [16]. Clinical studies have yielded conflicting results: Pena De La Vega and colleagues [36] found no difference in transplant outcomes between donors older or younger than 50, while Veroux and colleagues [6] observed that donor's age had a significant impact on graft outcomes, independently of recipient's age. 
Table 6. Multiple regression analysis: model 1

\begin{tabular}{|c|c|c|c|c|c|c|c|}
\hline \multirow[t]{2}{*}{ Model 1} & \multirow[t]{2}{*}{$B$} & \multicolumn{2}{|l|}{ CI 95\% } & \multirow[t]{2}{*}{ Odds ratio } & \multicolumn{2}{|c|}{ CI 95\% } & \multirow[t]{2}{*}{$p$ value } \\
\hline & & lower & higher & & lower & higher & \\
\hline \multicolumn{8}{|l|}{3 months } \\
\hline Donor's eGFR & 0.501 & 0.205 & 0.797 & 1.650 & 1.228 & 2.219 & 0.001 \\
\hline BMI & 1.125 & -0.089 & 2.338 & 3.080 & 0.915 & 10.360 & 0.069 \\
\hline Kidney size & 0.226 & -0.192 & 0.644 & 1.254 & 0.825 & 1.904 & 0.285 \\
\hline \multicolumn{8}{|l|}{12 months } \\
\hline Donor's eGFR & 0.543 & 0.223 & 0.863 & 1.721 & 1.250 & 2.370 & 0.001 \\
\hline BMI & 1.363 & 0.051 & 2.675 & 3.908 & 1.052 & 14.512 & 0.042 \\
\hline Kidney size & 0.365 & -0.087 & 0.817 & 1.441 & 0.917 & 2.264 & 0.112 \\
\hline \multicolumn{8}{|l|}{24 months } \\
\hline Donor's eGFR & 0.420 & 0.110 & 0.730 & 1.522 & 1.116 & 2.075 & 0.009 \\
\hline BMI & 1.036 & -0.235 & 2.306 & 2.818 & 0.791 & 10.034 & 0.108 \\
\hline Kidney size & 0.464 & 0.026 & 0.901 & 1.590 & 1.026 & 2.462 & 0.038 \\
\hline \multicolumn{8}{|l|}{36 months } \\
\hline Donor's eGFR & 0.290 & -0.021 & 0.602 & 1.336 & 0.979 & 1.826 & 0.067 \\
\hline BMI & 0.644 & -0.631 & 1.920 & 1.904 & 0.532 & 6.821 & 0.317 \\
\hline Kidney size & 0.148 & -0.292 & 0.587 & 1.160 & 0.747 & 1.799 & 0.504 \\
\hline
\end{tabular}

Donor's eGFR, donor's BMI, and kidney size were tested as independent variables to assess their effect on recipient's eGFR at different time points (dependent variable). Values in bold are statistically significant. eGFR, estimated glomerular filtration rate.

Table 7. Multiple regression analysis: model 2

\begin{tabular}{|c|c|c|c|c|c|c|c|}
\hline \multirow[t]{2}{*}{ Model 2} & \multirow[t]{2}{*}{$B$} & \multicolumn{2}{|l|}{ CI 95\% } & \multirow[t]{2}{*}{ Odds ratio } & \multicolumn{2}{|c|}{ CI 95\% } & \multirow[t]{2}{*}{$p$ values } \\
\hline & & lower & higher & & lower & higher & \\
\hline \multicolumn{8}{|l|}{3 months } \\
\hline Donor's age & -0.813 & -1.165 & -0.462 & 0.444 & 0.312 & 0.630 & $<0.001$ \\
\hline $\mathrm{BMI}$ & 1.483 & 0.325 & 2.641 & 4.406 & 1.384 & 14.027 & 0.013 \\
\hline Kidney size & 0.157 & -0.240 & 0.553 & 1.170 & 0.787 & 1.738 & 0.434 \\
\hline \multicolumn{8}{|l|}{12 months } \\
\hline Donor's age & -0.869 & -1.251 & -0.487 & 0.419 & 0.286 & 0.614 & $<0.001$ \\
\hline BMI & 1.745 & 0.488 & 3.002 & 5.726 & 1.629 & 20.126 & 0.007 \\
\hline Kidney size & 0.293 & -0.138 & 0.724 & 1.340 & 0.871 & 2.063 & 0.179 \\
\hline \multicolumn{8}{|l|}{24 months } \\
\hline Donor's age & -0.856 & -1.210 & -0.501 & 0.425 & 0.298 & 0.606 & $<0.001$ \\
\hline BMI & 1.428 & 0.260 & 2.595 & 4.170 & 1.297 & 13.397 & 0.017 \\
\hline Kidney size & 0.367 & -0.033 & 0.767 & 1.443 & 0.968 & 2.153 & 0.072 \\
\hline \multicolumn{8}{|l|}{36 months } \\
\hline Donor's age & -0.771 & -1.127 & -0.415 & 0.463 & 0.324 & 0.660 & $<0.001$ \\
\hline BMI & 1.010 & -0.161 & 2.181 & 2.746 & 0.851 & 8.855 & 0.090 \\
\hline Kidney size & 0.041 & -0.360 & 0.442 & 1.042 & 0.698 & 1.556 & 0.839 \\
\hline
\end{tabular}

Donor's age, donor's BMI, and kidney size were tested as independent variables to assess their effect on recipient's eGFR at different time points (dependent variable). Values in bold are statistically significant. eGFR, estimated glomerular filtration rate. 
Table 8. Multiple regression analysis: model 3

\begin{tabular}{|c|c|c|c|c|c|c|c|}
\hline \multirow[t]{2}{*}{ Model 3} & \multirow[t]{2}{*}{$B$} & \multicolumn{2}{|l|}{ CI $95 \%$} & \multirow[t]{2}{*}{ Odds ratio } & \multicolumn{2}{|c|}{ CI $95 \%$} & \multirow[t]{2}{*}{$p$ value } \\
\hline & & lower & higher & & lower & higher & \\
\hline \multicolumn{8}{|l|}{3 months } \\
\hline BMI & 1.318 & 0.151 & 2.486 & 3.738 & 1.163 & 12.010 & 0.028 \\
\hline Kidney size & 0.168 & -0.228 & 0.564 & 1.183 & 0.796 & 1.757 & 0.401 \\
\hline Donor's eGFR & -0.652 & -1.897 & 0.592 & 0.521 & 0.150 & 1.808 & 0.299 \\
\hline Age & -2.198 & -4.440 & 0.043 & 0.111 & 0.012 & 1.044 & 0.054 \\
\hline Donor's eGFR $\times$ age & 0.016 & -0.007 & 0.040 & 1.017 & 0.993 & 1.041 & 0.173 \\
\hline \multicolumn{8}{|l|}{12 months } \\
\hline $\mathrm{BMI}$ & 1.714 & 0.429 & 2.998 & 5.549 & 1.536 & 20.044 & 0.010 \\
\hline Kidney size & 0.279 & -0.157 & 0.715 & 1.322 & 0.855 & 2.044 & 0.205 \\
\hline Donor's eGFR & 0.336 & -1.033 & 1.705 & 1.399 & 0.356 & 5.504 & 0.626 \\
\hline Age & -0.461 & -2.927 & 2.005 & 0.631 & 0.054 & 7.429 & 0.710 \\
\hline Donor's eGFR $\times$ age & -0.003 & -0.029 & 0.023 & 0.997 & 0.972 & 1.024 & 0.832 \\
\hline \multicolumn{8}{|l|}{24 months } \\
\hline $\mathrm{BMI}$ & 1.419 & 0.217 & 2.622 & 4.135 & 1.242 & 13.764 & 0.021 \\
\hline Kidney size & 0.368 & -0.040 & 0.775 & 1.444 & 0.960 & 2.171 & 0.077 \\
\hline Donor's eGFR & -0.029 & -1.311 & 1.254 & 0.972 & 0.270 & 3.503 & 0.965 \\
\hline Age & -0.919 & -3.228 & 1.390 & 0.399 & 0.040 & 4.015 & 0.430 \\
\hline Donor's eGFR $\times$ age & 0.001 & -0.024 & 0.025 & 1.001 & 0.977 & 1.026 & 0.950 \\
\hline \multicolumn{8}{|l|}{36 months } \\
\hline BMI & 1.019 & -0.182 & 2.220 & 2.771 & 0.834 & 9.210 & 0.095 \\
\hline Kidney size & 0.052 & -0.355 & 0.460 & 1.054 & 0.701 & 1.584 & 0.798 \\
\hline Donor's eGFR & -0.308 & -1.588 & 0.973 & 0.735 & 0.204 & 2.646 & 0.633 \\
\hline Age & -1.197 & -3.503 & 1.109 & 0.302 & 0.030 & 3.033 & 0.304 \\
\hline Donor's eGFR $\times$ age & 0.004 & -0.021 & 0.028 & 1.004 & 0.979 & 1.028 & 0.775 \\
\hline
\end{tabular}

Donor's BMI and kidney size were tested as independent variables to assess their effect on recipient's eGFR at different time points (dependent variable), adjusted for donor's eGFR and age. Values in bold are statistically significant. eGFR, estimated glomerular filtration rate.

A recent survey describing the attitude of US transplant centers toward living kidney donor candidates showed that, starting in 2005, less strict criteria on age were applied. Between 2005 and 2017, the proportion of centers with no defined upper age limit for donation increased from 59 to $68 \%$. Of the centers which still applied an absolute upper age limit, the most common threshold was set at 70 years, as opposed to 65 in 2005 [21]. A similar trend in accepting older donors has been seen in France [37].

Obesity is a growing concern in the Western world, and the number of obese kidney donors is likely to increase in the future [38-40]. Once more, the literature is discordant: some studies have shown good perioperative outcomes for obese donors [41] and their kidney recipients [42], while others found that donor obesity is a risk factor for graft outcomes [28]. Our data are in keeping with this observation possibly because of the relatively small and homogeneous sample involved in the study and showed that the effect of kidney size or donor's BMI was negligible. The association between recipient's kidney function and BMI was only significant up to 24 months in the model considering donor's age, as well as in the model that combined the effect of donor's age and eGFR. This pattern highlights the need for larger prospective studies capable of further exploring these variables. Of note, however, is the fact that in our study average BMI of the donors was $24.28 \mathrm{~kg} / \mathrm{m}^{2}$ and only 6 donors had a BMI $>30 \mathrm{~kg} / \mathrm{m}^{2}$, previously identified as a risk threshold [28]; thus, our results should be interpreted with caution.

Likewise, previous studies found an association with donor's kidney size at ultrasounds or kidney volume at the CT scan or at the time of surgery and recipient's renal 
function [43-47]. Our data do not support a close correlation between donor's kidney size and recipient's kidney function, possibly because of the use of a less sensitive technique [48].

Gender match is an important factor in LDKT, especially because there is a disproportion between female and male donors [49]: our study did not support the controversial topic of a role of gender matching independently of other factors $[8,50,51]$. Our study suffers from several limitations. First of all, it is monocentric and complete data were not available for all donor-recipient pairs; furthermore, we did not adjust for immunosuppressive therapy; finally, due to the size of our cohort, we preferred to perform a regression model at each time point rather than fitting regression models for repeated measurements. These limitations may be partially offset by the homogeneity of the treatment and surgical policies followed at the transplant center and by the low incidence of acute rejection (1/90 cases) and primary disease recurrence (3/90 cases). Furthermore, we relied on available eGFR in the absence of more sophisticated data at all intervals. However, our study is addressed to a clinical audience, and the use of eGFR is the common practice of most transplant centers [21] and is in agreement with international guidelines [15]. Finally, the retrospective nature of this study does not allow for a cause-effect analysis of the parameters investigated.

\section{Conclusions}

Our study suggests the presence of a minor, albeit significant effect of donor's kidney function at time of transplantation on recipient's renal function during a 3-year follow-up period. However, this modest effect is compatible with a stable graft eGFR over follow-up even for recipients from donors with suboptimal renal function.
Nevertheless, when considering several donor characteristics, age seems to be a stronger predictor of future graft function than eGFR. We suggest that eGFR should be clinically balanced with other clinical and demographic determinants of kidney function, in particular age.

\section{Acknowledgements}

We would like to thank Patrick Saulnier for his advice on statistical questions and Susan Finnel for her careful language review.

\section{Statement of Ethics}

The results presented in this paper have not been published previously in whole or part, except in abstract format. Written consent was obtained from each patient. Medical data were collected from the database at Université Grenoble Alpes (CNIL [French national committee for data protection] approval number 1987785v0).

\section{Conflict of Interest Statement}

No author has a conflict of interest.

\section{Funding Sources}

The authors did not receive any funding.

\section{Author Contributions}

Research idea and study design: M.T., C.E., G.B.P., and P.M.; data acquisition: E.M. and T.J.; data analysis/interpretation: M.T., C.E., L.R., G.B.P., and P.M.; bibliographic search: M.C., E.P., V.E., and G.S.; statistical analysis: M.T., A.C., and G.B.P.; drafting: M.T., G.B.P., and P.M.; and final version: all authors.

\section{References}

1 Harrison JH, Merrill JP, Murray JE. Renal homotransplantation in identical twins. Surg Forum. 1956;6:432-6.

2 Wolfe RA, Ashby VB, Milford EL, Ojo AO, Ettenger RE, Agodoa LY, et al. Comparison of mortality in all patients on dialysis, patients on dialysis awaiting transplantation, and recipients of a first cadaveric transplant. N Engl J Med. 1999 Dec 2;341(23): 1725-30.

3 Kostro JZ, Hellmann A, Kobiela J, Skóra I, Lichodziejewska-Niemierko M, Dębska-
Ślizień A, et al. Quality of life after kidney transplantation: a prospective study. Transplant Proc. 2016 Jan-Feb;48(1):50-4.

4 Kaballo MA, Canney M, O’Kelly P, Williams Y, O'Seaghdha CM, Conlon PJ. A comparative analysis of survival of patients on dialysis and after kidney transplantation. Clin Kidney J. 2018 Jun;11(3): 389-93.

5 Saran R, Robinson B, Abbott KC, BraggGresham J, Chen X, Gipson D, et al. US renal data system 2019 annual data report: epidemiology of kidney disease in the United States. Am J Kidney Dis. 2020 Jan; 75(Suppl 1):A6-7.

6 Veroux M, Grosso G, Corona D, Mistretta A, Giaquinta A, Giuffrida G, et al. Age is an important predictor of kidney transplantation outcome. Nephrol Dial Transplant. 2012 Apr;27(4):1663-71.

7 Foley DP, Sawinski D. Personalizing donor kidney selection: choosing the right donor for the right recipient. Clin J Am Soc Nephrol. 2020 Mar 6;15(3):418-20. 
8 Naderi G, Azadfar A, Yahyazadeh SR, Khatami F, Aghamir SMK. Impact of the donorrecipient gender matching on the graft survival from live donors. BMC Nephrol. 2020 Jan 6;21(1):5

9 Garg AX, Prasad GV, Thiessen-Philbrook HR, Ping L, Melo M, Gibney EM, et al. Cardiovascular disease and hypertension risk in living kidney donors: an analysis of health administrative data in Ontario, Canada. Transplantation. 2008 Aug 15;86(3): 399-406.

10 Segev DL, Muzaale AD, Caffo BS, Mehta $\mathrm{SH}$, Singer AL, Taranto SE, et al. Perioperative mortality and long-term survival following live kidney donation. JAMA. 2010 Mar 10;303(10):959-66.

11 Garg AX, Meirambayeva A, Huang A, Kim J, Prasad GV, Knoll G, et al. Cardiovascular disease in kidney donors: matched cohort study. BMJ. 2012 Mar 1;344:e1203.

12 Mjoen G, Hallan S, Hartmann A, Foss A, Midtvedt K, Oyen O, et al. Long-term risks for kidney donors. Kidney Int. 2014 Jul; 86(1):162-7.

13 Muzaale AD, Massie AB, Wang MC, Montgomery RA, McBride MA, Wainright JL, et al. Risk of end-stage renal disease following live kidney donation. JAMA. 2014 Feb 12; 311(6):579-86.

14 Abramowicz D, Cochat P, Claas FH, Heemann U, Pascual J, Dudley C, et al. European renal best practice guideline on kidney donor and recipient evaluation and perioperative care. Nephrol Dial Transplant. 2015 Nov;30(11):1790-7.

15 Lentine KL, Kasiske BL, Levey AS, Adams PL, Alberú J, Bakr MA, et al. Summary of kidney disease: improving global outcomes (KDIGO) clinical practice guideline on the evaluation and care of living kidney donors. Transplantation. 2017 Aug;101(8):178392.

16 Andrews PA, Burnapp L. British transplantation society/renal association UK guidelines for living donor kidney transplantation 2018: summary of updated guidance. Transplantation. 2018;102(7):e307.

17 Mandelbrot DA, Reese PP, Garg N, Thomas $\mathrm{CP}$, Rodrigue JR, Schinstock C, et al. KDOQI US commentary on the 2017 KDIGO clinical practice guideline on the evaluation and care of living kidney donors. Am J Kidney Dis. 2020 Mar;75(3):299-316.

18 Reese PP, Caplan AL, Kesselheim AS, Bloom RD. Creating a medical, ethical, and legal framework for complex living kidney donors. Clin J Am Soc Nephrol. 2006 Nov; 1(6):1148-53.

19 Kumar A, Mandhani A, Verma BS, Srivastava A, Gupta A, Sharma RK, et al. Expanding the living related donor pool in renal transplantation: use of marginal donors. J Urol. 2000 Jan;163(1):33-6.
20 Kumar A, Das SK, Srivastava A. Expanding the living related donor pool in renal transplantation: use of marginal donors. Transplant Proc. 2003 Feb;35(1):28-9.

21 Garg N, Lentine KL, Inker LA, Garg AX, Rodrigue JR, Segev DL, et al. The kidney evaluation of living kidney donor candidates: US practices in 2017. Am J Transplant. 2020 Dec;20(12):3379-89.

22 Levey AS, Inker LA. GFR evaluation in living kidney donor candidates. J Am Soc Nephrol. 2017 Apr;28(4):1062-71.

23 Gaillard F, Courbebaisse M, Kamar N, Rostaing L, Del Bello A, Girerd S, et al. The agecalibrated measured glomerular filtration rate improves living kidney donation selection process. Kidney Int. 2018 Sep;94(3): 616-24.

24 Norden G, Lennerling A, Nyberg G. Low absolute glomerular filtration rate in the living kidney donor: a risk factor for graft loss. Transplantation. 2000 Nov 15;70(9): 1360-2.

25 Godinho I, Guerra J, Melo MJ, Neves M, Gonçalves J, Santana MA, et al. Living-donor kidney transplantation: donor-recipient function correlation. Transplant Proc. 2018 Apr;50(3):719-22.

26 Young A, Kim SJ, Garg AX, Huang A, Knoll $\mathrm{G}$, Prasad GV, et al. Living kidney donor estimated glomerular filtration rate and recipient graft survival. Nephrol Dial Transplant. 2014 Jan;29(1):188-95.

27 Levey AS, Stevens LA, Schmid CH, Zhang YL, Castro AF 3rd, Feldman HI, et al. A new equation to estimate glomerular filtration rate. Ann Intern Med. 2009 May 5;150(9): 604-12.

28 Naik AS, Zhong Y, Parasuraman R, Doshi M, Norman S, Lu Y, et al. The temporal and long-term impact of donor body mass index on recipient outcomes after kidney transplantation: a retrospective study. Transpl Int. 2020 Jan;33(1):59-67.

29 Weitz J, Koch M, Mehrabi A, Schemmer P, Zeier M, Beimler J, et al. Living-donor kidney transplantation: risks of the donor: benefits of the recipient. Clin Transplant. 2006;20(Suppl 17):13-6.

30 Glassock RJ, Rule AD. Aging and the kidneys: anatomy, physiology and consequences for defining chronic kidney disease. Nephron. 2016;134(1):25-9.

31 Glassock RJ, Denic A, Rule AD. The conundrums of chronic kidney disease and aging. J Nephrol. 2017 Aug;30(4):477-83.

32 Glassock RJ, Delanaye P, Rule AD. Should the definition of CKD be changed to include age-adapted GFR criteria? YES. Kidney Int. 2020;97(1):34-7.

33 Levey AS, Inker LA, Coresh J. Should the definition of CKD be changed to include age-adapted GFR criteria? con: the evaluation and management of CKD, not the definition, should be age-adapted. Kidney Int. 2020;97(1):37-40
34 Rovin $\mathrm{BH}$. Do kidneys grow old gracefully? Kidney Int. 2020;97(1):40-1.

35 Denic A, Glassock RJ, Rule AD. Structural and functional changes with the aging kidney. Adv Chronic Kidney Dis. 2016 Jan; 23(1):19-28.

36 Pena De La Vega LS, Torres A, Bohorquez HE, Heimbach JK, Gloor JM, Schwab TR, et al. Patient and graft outcomes from older living kidney donors are similar to those from younger donors despite lower GFR. Kidney Int. 2004 Oct;66(4):1654-61.

37 Gaillard F, Jacquemont L, Roberts V, Albano L, Allard J, Bouvier N, et al. Temporal trends in living kidney donation in France between 2007 and 2017. Nephrol Dial Transplant. 2019 Nov 28;gfz229.

38 Sachdeva M, Rosen LM, Varghese J, Fishbane S, Molmenti EP. Weight trends in United States living kidney donors: analysis of the UNOS database. World J Transplant. 2015 Sep 24;5(3):137-44.

39 Collaboration NCDRF. Worldwide trends in body-mass index, underweight, overweight, and obesity from 1975 to 2016: a pooled analysis of 2416 population-based measurement studies in 128.9 million children, adolescents, and adults. Lancet. 2017 Dec 16;390(10113):2627-42.

40 Uppal N, Chang BF, Sakhiya V, Hasan A, Sachdeva M. 321 pre-donation weight trends over the past twenty years in US living kidney donors: analysis of UNOS database. Am J Kid Dis. 2019;73(5):727.

41 Takagi K, Kimenai HJAN, IJzermans JNM, Minnee RC. Obese living kidney donors: a comparison of hand-assisted retroperitoneoscopic versus laparoscopic living donor nephrectomy. Surg Endosc. 2020;34(11): 4901-8.

42 Reese PP, Feldman HI, Asch DA, Thomasson A, Shults J, Bloom RD. Short-term outcomes for obese live kidney donors and their recipients. Transplantation. 2009 Sep 15;88(5):662-71.

43 Paleologo G, Abdelkawy H, Barsotti M, Basha A, Bernabini G, Bianchi A, et al. Kidney dimensions at sonography are correlated with glomerular filtration rate in renal transplant recipients and in kidney donors. Transplant Proc. 2007 Jul-Aug; 39(6): 1779-81.

44 Buturovic-Ponikvar J, Cerne S, Arnol M, Kandus A, Ponikvar R, Bren A. Early kidney graft size and doppler parameters are associated with kidney graft function 1 year after transplantation. Transplant Proc. 2010 Dec;42(10):4026-9.

45 Tanriover B, Fernandez S, Campenot ES, Newhouse JH, Oyfe I, Mohan P, et al. Live donor renal anatomic asymmetry and posttransplant renal function. Transplantation. 2015 Aug;99(8):e66-74.
Donor's Influence on Living Kidney Transplant
Kidney Blood Press Res 2021;46:84-94 DOI: $10.1159 / 000512177$ 
46 Al-Adra DP, Lambadaris M, Barbas A, Li Y, Selzner M, Singh SK, et al. Donor kidney volume measured by computed tomography is a strong predictor of recipient eGFR in living donor kidney transplantation. World J Urol. 2019 Sep;37(9):1965-72.

47 Vasconcelos Ordones F, Pajolli PIR, Guerra da Silva R, Yamamoto HA, Gomes Filho FF, Kawano PR, et al. Impact of adjusted kidney volume measured in the bench surgery on one-year renal function in kidney transplantation. PLoS One. 2019;14(11): e0224364.

48 Van Den Noortgate N, Velghe A, Petrovic $\mathrm{M}$, Vandewiele C, Lameire N, Voet D, et al. The role of ultrasonography in the assessment of renal function in the elderly. $J$ Nephrol. 2003 Sep-Oct;16(5):658-62.
49 Oien CM, Reisaeter AV, Leivestad T, Pfeffer P, Fauchald P, Os I. Gender imbalance among donors in living kidney transplantation: the Norwegian experience. Nephrol Dial Transplant. 2005 Apr;20(4):783-9.

50 Miller AJ, Kiberd BA, Alwayn IP, Odutayo A, Tennankore KK. Donor-recipient weight and sex mismatch and the risk of graft loss in renal transplantation. Clin J Am Soc Nephrol. 2017 Apr 3;12(4):669-76.

51 Morgan G, Goolam-Mahomed Z, Hodson J, Nath J, Sharif A. Donor-recipient sex differences do not affect survival outcomes after kidney transplantation: a population cohort study. Transplantation. 2020 May; 104(5): 1033-40.
52 Poggio ED, Hila S, Stephany B, Fatica R, Krishnamurthi V, del Bosque C, et al. Donor kidney volume and outcomes following live donor kidney transplantation. Am J Transplant. 2006 Mar;6(3):616-24.

53 Issa N, Stephany B, Fatica R, Nurko S, Krishnamurthi V, Goldfarb DA, et al. Donor factors influencing graft outcomes in live donor kidney transplantation. Transplantation. 2007 Mar;1583(5):593-9.

54 Chang SS, Hung CJ, Lin YJ, Chou TC, Chung PY, Lin YS, et al. Association between preoperative allograft function (effective renal plasma flow) and the change in glomerular filtration rate among living-donor kidney transplant recipients. Transplant Proc. 2012 Jan;44(1):248-53. 